easily accounted for; the oxygen is attracted by the lieated metal, and unites with it, and the hydrogen is liberated.

The alleged improbability of the large quantities of the two gases which are requisite to form the water of the globe existing in nature has very little weight. In the same way we might disbelieve half the facts in astronomy; but this is not very scientific reasoning any more than the next argument, which stands thns-water is a powerful extinguisher of flame; therefore it is unlikely for it to be composed of inflammable materials.

Now, if in chemistry it were a law that the properties of compounds necessarily assimilate to those of their constituents, this argument would have much weiglut; but as every chemist knows that the very contrary may be, and often is, the case, it has none whatever. Water is not the only compound of combustible substances that is potent in extinguisling; carbonic acid (like it, made up of inflammable materials) acts quite as effectually. What is the usual phenomenon of combustion? Why, the combiuation of carbon and hydrogen with oxygen, forming carbonic acid and water, which, liaving reached their highest state of combination or combustion, are obviously incapable of buming any more; but as by their contact with flame they prevent the access of uncombined air or oxygen, they stop the combustion.

As for Dr. Priestley's always finding the water produced by the union of the two gases, acid, I believe the canse to have been some impurity in them, and I do not see how the fact is otherwise explicabie either on Mr. Stevenson's or the conmon opinion.

And now let me notice a fact or two, certainly dinicalt of explanation, on the supnosition of water being $\varepsilon_{\text {simple body. }}$ How, on such hypothesis, can we account for the constant presence in water of oxygen, always in a definite proportion, and in so firm a state of combination, that no means we at present possess will separate even an atom of this without also setting free an equivalent of hydrogen, and vice versit. This is a well-established fact; the experiments which prove it are so well known that $I$ need only nention one-viz, the decom. position (as I think we are still justified in terming it) of water by the voltaic current, by which hydrogen and oxygen are always evolved rigorously, in the proportions of two volumes of the former to one of the latter. Now, is the oxygen here held in solution by the water? then why is it always in one proportion, and as constantly with an equivalent quantity of hydrogen? If water were a simple body, it would not, judging from its behaviour with respect to other gases which it dissolves, always contain the oxygen in one proportion, nor would it cling to it with such tenacity that the gas can never be separated without causing the fluid to change its form! In short, all facts at present lead irresistibly to the conclusion, that the presence of oxygen is absolutely essential to the existence of water, and in a state of chemical combination; and unless Mr. Stevenson can prove the contrary, by producing water from hydrogen without axygen, or in showing a specimen of water from which no oxygen can be oltained, his gas theory must be considered as exploded.

I remain, Sir, yours obediently,

Kirton-Lindsey, April 8, 1850.

H. J. WATERLand.

\section{MURDERS BY INSANE PERSONS.}

\section{To the Editor of The LANCET.}

SIR,-Two or three weeks ago, an insane person, named Pearson, murdered his medical adviser, $\mathrm{Dl}_{1}$. Wilson, and the latter's mother. It appears that the patient had been formerly in a lunatic asylum, for having threatened to kill a elergyman, and my object in miting is, to inquire, through your pages, if any information can be obtained, by whose authority or advice this man Pearson was liberated from the lunatic asylum, and permitted to go free.

It appears to me very obvious that the party or parties, whether parochial, medical, or other, who sanctioned his being set at large, after his having manifested so decided a disposition to murder, as to warrant his being once shut up, are in some measure responsible for the dreadful murders which have ensued, and that the relatives of the murdered parties ought to have grounds for raising an action of damages and compensation for the loss and shock which they must have sustained.

Several cases of this kind have lately happened, and, so far as I can perceive, no adequate notice has been taken by either the medical or general press, of the atrociously-culpable negligence which must have been chargeable somewhere, and on some parties, for allowing insane persons who had manifested homicidal tendencies to be at large. We earnestly trust that this notice of the subject may, by awakening the attention of the profession, spare us a repetition of such a revolting and disgraceful tragedy as the late one at Juniper-green.

It may be said, "What! shut up a man for life because he has once been the subject of homicidal mania?" We reply decidedly in the affirmative. We point to the many instances, similar to the above, which justify the measure. We may pity the patient, but we ought to look upon the necessity for his restraint as but an unavoidable consequence of the previous misfortuno (insanity) inflicted on him by Providence. While we commiserate lim ne comst not forget the sane, whose lives are every noment in jeopardy from the possible recurrence of the most fifful and capricious of all diseases.

The restraint need not, in all cases, be to the ralls of an asylum, but, in favourable cases, may consist in the constant superintendence of a responsible keeper. The point we insist on is, that an insane person who has once manifested unequivocal signs of homicidal tendencies, onght never thereafter to be wholly his own master.

The relatives of the insane, if in suitable circumstances, should, of conrse, be compelled by law to provide adequato restraint, and should be made responsible for any untoward results arising from their not having done so. Insane panpers should be confined or guarded at the public charge. The expense would bo inconsiderable. Probably there are not ten persons in Scotland, and three or four times that number in Fnglaud and Ireland, who, were such a law as I speak of put in force to-morrow, would require keeping, in addition to those now under restraint. And what would be the paltry expense to the priblic of taking charge of this small number, in comparison to the importance of the good obtained, and to the prevention of such lideons catastrophes as thut of Junipergreen? I am, Sir, your obedient servant, Norfolk-tirrace, Westbourne-grore, West. Rosenm Drek.

\section{THE REGISTRATION OF DEATHS, AND MEDICAL} CERTIFICATES.

TO THE REGISTRAR GEXERAE.

Sre,- I Iitherto I have considered that the "medical certificate of the cause of death" was a protective security demanded from the medical profession by the public-that is to say, an official guarantee that death had fairly fallen to the person. I likewise considered that when this docment was withheld, but one other functionary (for every medical man, from the nature of his vocation, is necessarily a public officer) could supply the deficiency, and that in this case it was imperative on hin to do so, since the local registrar, without the one testimony or the other, conld not legally furnish his certificate. The second party to whom $I$ allude is the coroner. I thought that in the event of no medical man having been consulted, and no suspicion attaching, that the testimony of a person present at the death was sufficient for its due registrationalthough, by the way, $I$ always considered that even here a medical certificate should not be dispensed with-since there should be an accredited medical man even to report on this, and thus, as it were, hem in death by the police of medicine and the court of the coroner.

I have become, however, painfully arvare of the fallacy of all this supposition, lately. My own child died. I forwarded by the undertaker the usual medical certificate to the registrar of my district. This was put aside, with the observation that it was worthless, and that some one must attend who had witnessed the decease-a servant would do. I attended myself, and, as a private individual, did as well as a servant; and so the matter ended. I learned from the registrar that this was not an exception in my case, but his practice invariably. Thus it seems that three persons may be living together; two of these may conspire to kill the third, and the testimony of one of the conspirators is enough for the burial of the victim. Even more; if it may have answered the purpose to call in a medical man, whose suspicions may have been just enough excited to cause his withlolding his certificate, still, even with this known to the registrar, (so supposing it, the requirement of his office can be readily supplied.

There is in this a wilful laxity of protection to the public, very scandalous to common sense, but perhaps very creditable to the official feeling which begets it - the genuine English official feeling of degrading the medical profession. The medical profession can very well afford this, in a nation of shopkeepers and harpy attorneys, where respectability means paying the way, and learning the mire of man's roguery. But still one would think that both respectability and learning 
would so far respect the sacredness of their own lives as to concede so much of their double monopoly to medicine as would enable it to exercise the little authority of a protective veto in a matter so really vital, and the more especially, when Messrs. Styles and Hawk could get it on their usual liberal terms of medical remuneration-free-gratis, for nothing.

Since I find that the medical certificate of the cause of death is not of sufficient respectability to be of any practical value beyond, perhaps, the making up of reports, and conscious as I am that we possess in the profession, and are sure always to obtain, sufficient statistics for the working out of public benefit, I shall, in future, in the course of practice, withhold the usual document-and I shall also use my influence, both public and private, with my professional brethren, to get them to do so likewise.

I am, Sir, your most obedient servant,

Dean's-row, Walworth-road, W. H. BRown, M.D., F.L.S., April, 1850.

Lecturer at the Charing-cross Hospital

\section{DEAFNESS AND NOISES IN THE EARS.} To the Editor of Trie LANCET.

SrR,-One reason may be assigned for the silence of the pro. fession, which is, that your querist has united two questions entirely dissimilar. $x$ Deafness exists without noises in the ear, and noises in the ear exist with more of a sense of confusion in hearing than with positive deafness.

Mnises in the ear are produced by two causes, which prevent the proper ribration of the membrana tympani-an accumulation of cerumen in the meatus auditorius, and occlusion of the Eustachian tube. Hence the frequency of these noises during catarrh, and their removal by syringing the ears, or by inflating the Eustachian tubes in the ordinary way, by compressing the nostrils, and forcibly blowing the nose. But there are other noises of which persons complain, which are neither so simple in their origin nor so easily removed, such as musical sounds or regular tunes repeated again and again, voices singing and speaking, bells ringing, \&c. The seat of these noises is not the ear, but the brain. They are often the renewal of a morbid condition of the brain of former impressions. They depend entirely on the state of the constitution and on the circulation through the brain.

The distress to which they give rise is dreadful in sane persons, and in the insane they constitute prominent symptoms of their insanity. They cease under the use of means directed to the removal of the morbid condition and irregular circulation, on which they depend. 'The means by which this is to be accomplished must be adapted to the nature of the case.

'The subject of deafness is quite of another kind. It may arise from a variety of causes, but permanent deafness, for the most part, is occasioned either by some change in the organ, produced by disease, or in the nervous apparatus subservient to the sense of hearing. $X$ The conditions necessary for distinct hearing are a perfect organ and sound auditory nerves.

As a parting advice to your correspondent, I would strenuously urge upon him to be very careful in the selection of an ear-doctor, or aurist. The ear has afforded a rich harvest for the harpies who prey upon the infirmities of human nature. It is possible to stimulate a paralyzed ear, as it is a paralyzed leg by the lash, but the effort only increases the paralysis. The attention of a deaf person may be roused by means directed to the cure of the deafness, and the patient may be deceived into a notion that he hears more distinctly, but soon his attention becomes wearied, and his hopes of amendment vanish. When deafness and noises in the ear depend upon disorder of health, they are curable by remedies directed to the state of the health, but not by remedies applied to the ear. The eye has not been so frequently and so cruelly tampered with as the ear, and for this obvious reasonthe evil as well as the good of local treatment is more manifest. I am, Sir, yours,

Philotos.

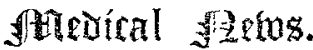

Royal Colugge of Physicians.-Gentlemen admitted members, Monday, March 28.

Cla RKe, Dr. John.

Hare, Dr. Charles John.

Pollock, Dr. James EDWARD.

WADHAM, Dr. WILLTAM.

Aprointment.-L. M. Peck, Esq., M.R.C.S., of Newmarket, has been appointed Deputy-Coroner for Cambridgeshire.
Royal College of Surgeons.-The following gentlemen having undergone the necessary examinations for the diploma, were admitted members of the college at the meeting of the Court of Examiners on the 12th inst.:-

Brayan, Frederick Williams Calwaltader, Blenchland, Northumberland.

Caird, Thomas Wilson, Exeter.

Effendi, Halib Aga Risk Altah, Syria.

Grifrith, Grifrith Hooper, Cheltenham.

LitTLE, John, Ballina, county Mayo, Ireland.

Mayhew, H. Jeremiah, Overhall, Colne Engaine, Essex.

Mountrond, John Bidlake, Exeter.

PATIENT, $\boldsymbol{J}_{\text {AMIES }}$, Corton, Wiltshire.

Penfold, Henry, Annington, Steyning, Sussex.

Roper, Charles Harriott, Exeter.

SAUNDERS, DANIEI, Llandovery, Carmarthenshire.

Apothecarmes' Hall.-Names of gentlemen who passed their examination in the science and practice of medicine, and received certificates to practise, on

$$
\text { Thursday, A pril 11th, } 1850 .
$$

Barwis, Thomas Leonard Barber, Penryn, Cornwall.

BrEAcH, J AMES, Bradfield.

Buckle, Robert Thomas, Bedall, Yorkshire.

Dayis, Henry May, Hastings.

HiLL, ALFRED, Walsall.

Martin, Frederick, Clare, Suffolk.

M'Cormick, J. VANDERSLOOT, Acton-street, Gray's-inn-road.

Pesketr, Alfred, Petersfield, Hants.

Plumptre, Francis Menry, Queen's-square.

Schrokder, Henry Sacheverel Edward, Guernsey.

WALKer, John West, Spilsby.

Whitchurof, Reuben, Melton Mowbray.

Wilson, Janes, Lancaster.

Universitx College.-Our readers are doubtless aware of the disturbances which took place about five weeks ago at University College, in consequence of the "rustication" of two students by the Council, and that the College was restored to its " usual tranquillity" upon the Council reversirg their decision, at the recommenlation of the professors. A renewal of these disturbances having taken place last Saturday afternoon, (April 13th,) it is necessary that the true facts of the case should be laid before the public:-Three students had been summoned "to appear before the Council, on that day, to answer a charge of misconduct towards Mr. Champion, the sub-librarian of the general library, on the 1st of A pril." Before the hour of investigation arrived, a considerable number of police was stationed near the gates of the College, and the adjoining streets. This attracted to the College a few of the students remaining in town during the vacation, amounting in number, as was afterwards ascertained, to twenty-six. After an inquiry, which lasted two hours, the Council decided that the charge was not proved, otherwise they expressed their determination to have resorted to the utmo:t extent of punishment in their power. When the three accused came out from the Council room, they were cheered by their fellow-students, who were waiting outside in the cloisters to hear the result; some of the professors coming forward at the same time, were greeted with lond cheers; but the appearance of the Council, on the other hand, excited an irrepressible burst of laughter; some of them turned back, and one of their number coming up to a student demanded his name; this was refused, whereupon, seizing him by the arm, he cried, "Police, take this man in clarge!" The students raised a shout of "No! no!" which was replied to, on the part of the Council, by loud cries of "Yes! ses!" None of the police appeared, but several strange men (who were afterwards discovered to be police in disguise) rushed from a place of concealment, and lid hands on the student; in consequence of this a general mêlée ensued, in which the students succeeded in rescuing their fellow; two other students being also seized were similarly rescued; after this, at the earnest desire of the professors, the students went away quietly; after the lapse of a few minutes the police, who had hitherto remained quiet in the strect, marched in, and took up their position in the cloisters of the College, where they remained a short time, and then marehed out

Royal Veterinary College.-A large meeting of the students of the above institution took place at the Freemasons' Tavern, on Thursday evening last, for the purpose of presenting to Professor Sinionds a handsome silver epergne, on which the usual complimentary donative inscription was engraved. The other professors were present by invitations of the class, and during the evening the most friendly sentiments towards each other were exchanged, and the greatest unanimity existed. It is pleasing to be able from time to time 